\title{
Inhibition of peptic activity by carbenoxolone and glycyrrhetinic acid
}

F. D. HENMAN 1

From the Research Laboratories, May \& Baker Ltd, Dagenham, Essex

SUMMARY Carbenoxolone (Biogastrone, Berk) has been shown to reduce the peptic activity and total acidity of gastric juice obtained from anaesthetized pylorus-ligated rats without affecting significantly the volume of gastric juice secreted or the $\mathrm{K}^{+}$concentration. Glycyrrhetinic acid was less potent in reducing peptic activity and caused no reduction in totalacidity.

Antipeptic activity of carbenoxolone has also been demonstrated in vitro using the pepsin plate technique and the haemoglobin pepsin assay.

It is suggested that these actions of carbenoxolone may contribute to the increased rate of healing of peptic ulcer in patients treated with the drug.

Liquorice extract has been used in the treatment of peptic ulcers for centuries without any particular rationale. Its activity is believed to be associated with the glycoside, glycyrrhizinic acid, hydrolysis of which yields glycyrrhetinic acid (1) [3,hydroxy-11-oxo-18ßolean-12-en-30-oic acid]. Carbenoxolone sodium (2) is the disodium salt of glycyrrhetinic acid hemisuccinate, and is marketed as Biogastrone (Berk). It is claimed to be of value in the treatment of gastric ulcer but is of little value in the treatment of duodenal ulcer. Several clinical trials have been reported in recent years on the efficacy of carbenoxolone in gastric ulcer therapy. For instance Doll, Hill, Hutton, and Underwood (1962), Doll, Hill, and Hutton (1965), and Horwich and Galloway<smiles>CC1(C(=O)O)CCC2(C)CCC3(C)C(=CC(=O)C4C5(C)CCC(O)C(C)(C)C5CCC43C)C2C1</smiles>

(1)<smiles>CC(=O)OC1CCC2(C)C(CCC34CC35CCC3(C)CCC(C)(C(=O)O[Na])CC3C5=CC(=O)C24)C1(C)C</smiles>

(2) 
(1965) showed that carbenoxolone increased the rate of healing of gastric ulcers. However, Middleton, Cooke, Stephen, and Skyring (1965) did not confirm these results in non-ambulant gastric ulcer patients. Turpie and Thomson (1965) reported a pronounced incidence of troublesome side effects such as oedema, hypertension, and hypokalaemia that seemed to result from the mineralocorticoid activity possessed by carbenoxolone, a factor that limits the dose that can be given (Fletcher, MacKay, and Forbes, 1967). Doll, Langman, and Shawdon (1968) showed that spironolactone antagonized both the mineralocorticoid side effects of carbenoxolone and its ulcer-healing properties. Doll et al (1962) saw no effect with Biogastrone tablets on duodenal ulcers. Recently, coated capsules of carbenoxolone have been introduced as a suggested treatment for duodenal ulcers (Duogastrone, Berk).

There is little information in the literature on the pharmacology of carbenoxolone. It is known to possess anti-inflammatory activity (Finney and Somers, 1958), an action probably related to the release of corticoids from the adrenals (Khan and Sullivan, 1968). Carbenoxolone uncouples oxidative phosphorylation, being less potent than glycyrrhetinic acid in this respect. Both compounds bind with bovine plasma albumin, carbenoxolone to a greater degree than the parent acid (Whitehouse, Dean, and Halsall, 1967).

The mode of action of carbenoxolone in helping to heal gastric ulcers is unknown. It has been shown by Parke, Pollock, and Williams (1963) and Iveson, Parke, and Williams (1966) that carbenoxolone is rapidly absorbed into the blood stream from the stomach so that a systemic effect on healing cannot be ruled out. It is excreted in the bile as the glucuronide. Hunt (1965) stated that it had no known action on gastric motility or gastric acid secretion, but Banks, Marks, Palmer, Groll, and Van Eldik (1967) commented on a reduction in maximal acid output in histamine gastric function tests in man. There is also evidence that secretion of mucus is enhanced (Dean, 1968) and it has been suggested that the layer of mucus protects the ulcer from the action of acid and pepsin (Hunt, 1965).

The experiments described in this paper show that carbenoxolone inactivates pepsin whilst reducing the total acidity of the gastric juice and it is suggested that these effects could contribute to the therapeutic activity of the drug.

As standards for comparisons of the antipeptic activity of carbenoxolone, three preparations were used: (1) glycyrrhetinic acid; (2) Roter (F.A.I.R.), a mixture of bismuth subnitrate, magnesium carbonate, and sodium bicarbonate, claimed to be of value in the treatment of peptic ulceration; and (3) a degraded carregeenan in the form of Ebimar tablets (Evans Medical), previously shown to possess antipeptic activity and to protect experimental animals against peptic ulceration (Levey and Sheinfeld, 1954; Anderson, 1961a and b; Anderson and Harthill, 1967).

\section{Methods}

1 PYLORUS-LIGATED RATS

Female Sprague-Dawley rats $(180-220 \mathrm{~g})$ were deprived of food overnight but given free access to $5 \%$ dextrose and $0.2 \%$ sodium chloride in distilled water. Solutions were prepared so that $2 \mathrm{ml}$ of solution contained the weight of compound required by $1 \mathrm{~kg}$ body weight. Solutions were administered orally in a volume of $2.0 \mathrm{ml} / \mathrm{kg}$. Control animals received only sodium bicarbonate solution at $p \mathrm{H} 7 \cdot 0-8 \cdot 0$. The pylorus was ligated while the animals were anaesthetized with $40 \mathrm{mg} / \mathrm{kg}$ pentobarbitone sodium given intraperitoneally. Four hours later the rats' stomachs were removed. The contents were centrifuged at $3,000 \mathrm{rpm}$ for 10 minutes and were assessed for volume, total acid concentration, peptic activity, and $\mathrm{K}^{+}$ concentration (see method 2).

A chronic experiment was undertaken to investigate the possibility that the antipeptic activity of carbenoxolone could be cumulative with prolonged dosage, and also the suggested antagonism of carbenoxolone's activity by spironolactone. Three groups of 16 rats each were treated daily with $2 \mathrm{ml} / \mathrm{kg}$ of the appropriate solutions. The first group received $10 \mathrm{mg} / \mathrm{kg}$ carbenoxolone orally each day, the solution being prepared as described below. A second group received $10 \mathrm{mg} / \mathrm{kg}$ carbenoxolone $+2 \cdot 5$ $\mathrm{mg} / \mathrm{kg}$ spironolactone orally each day, both drugs being dissolved in the same solution. The third control group received a solution of sodium bicarbonate. The $p \mathrm{H}$ of all three solutions was checked and when necessary adjusted to 7.0 with dilute hydrochloric acid. During treatment the weight of food eaten and the volume of water drunk by each cage of rats were recorded for each 24-hour period and expressed as $\mathrm{g} / 100 \mathrm{~g}$ body weight/day and $\mathrm{ml} / 100 \mathrm{~g}$ body weight/day respectively. After 17 days' treatment eight of each of the three groups of rats were subjected to pyloric ligation as described above, and the remaining 24 rats were similarly used after a further six days' treatment. In both cases the final doses of the appropriate solutions were administered before the administration of the anaesthetic and pyloric ligation.

2 GASTRIC JUICE ANALYSIS METHODS

\section{Pepsin}

The method was essentially that of Anson (1938) 
as modified by Aitken, Spray, and Walters (1954) except that dilutions were made by these authors with hydrochloric acid at $p \mathrm{H} 1 \cdot 5$.

One in 100 dilutions of the centrifuged gastric juice samples obtained from pylorus-ligated rats were prepared in dilute hydrochloric acid $(p \mathrm{H}$ 2.00 ). One $\mathrm{ml}$ of each dilution was incubated with $2 \%$ haemoglobin $(5 \mathrm{ml})$ dissolved in the same hydrochloric acid at $37^{\circ} \mathrm{C}$. After 10 minutes the reaction was stopped by the addition of $0.3 N$ trichloracetic acid $(10 \mathrm{ml})$ and inverting the tube once. The solution was filtered through a Whatman no. 1 filter paper. A portion $(5 \mathrm{ml})$ of the filtrate was made alkaline by adding $0.5 \mathrm{~N} \mathrm{NaOH}(10 \mathrm{ml}) ; 3 \mathrm{ml}$ of a 1 in 3 dilution of Folin-Ciocalteu reagent was then added with care down the side of the test tube which was inverted once. The optical density was measured 10 to 20 minutes later on a Unicam SP 600 spectrophotometer at $660 \mathrm{~m} \mu$. Blanks were prepared using $1 \mathrm{ml}$ of dilute $\mathrm{HCl}$ instead of the gastric juice dilution and the mean value of the blanks was subtracted from the optical density readings to give a correct reading. Pepsin concentrations were calculated from a calibration curve previously prepared. All determinations were carried out in duplicate.

\section{Total acid}

Samples $(0 \cdot 1 \mathrm{ml})$ of gastric juice were titrated against $0.01 \mathrm{~N}$ sodium hydroxide with phenol red as indicator. All determinations were done at least twice. The results were expressed as $\mathrm{m}$-equiv/ml.

\section{Potassium $\left(\mathrm{K}^{+}\right)$}

The 1 in 100 dilutions prepared for pepsin assay were submitted to flame photometry. The $\mathrm{K}^{+}$ concentration in parts per million was ascertained from a calibration curve.

\section{ANTIPEPTIC ACTIVITY IN VITRO}

\section{Haemoglobin digestion}

Serial dilutions of carbenoxolone were made in hydrochloric acid at a $p \mathrm{H}$ of 2.0 when $75 \mu \mathrm{g} / \mathrm{ml}$ pepsin was present and at a $p \mathrm{H}$ of 3.6 with $2 \mathrm{mg} /$ ml pepsin.

A Roter tablet ( $\equiv 350 \mathrm{mg}$ bismuth subnitrate) was ground in a mortar and the antacids were neutralized with hydrochloric acid. From the resulting suspension, serial dilutions were prepared similarly to those with carbenoxolone.

A suspension of Ebimar (1 tablet $\equiv 0.5 \mathrm{~g}$ carrageenan substance) in distilled water was also serially diluted.

The procedure described above for pepsin was used to assay antipeptic activity in the samples. The haemoglobin substrate was made up in hydrochloric acid at $p \mathbf{H} 3.6$ for use with dilutions in this medium. Optical density readings were compared with control readings. All determinations were carried out in quadruplicate.

\section{Pepsin plates}

Pepsin plates were prepared by the method of Carter and Sykes (1961). Plates were used in $\Omega$ pairs, each pair having 32 cups. Pepsin solution, with or without carbenoxolone, Roter, or $\overrightarrow{\vec{s}}$ Ebimar, was made up in half-strength Mcllwaine $\overline{0}$ buffer $(p H 3.5)$ such that the amount of pepsin $\frac{}{\sigma}$ in the $0.02 \mathrm{ml}$ was either 1 or $10 \mu \mathrm{g}$. The con- $\frac{\bar{p}}{\bar{p}}$ centration of the drug was varied, and five or $\overparen{\otimes}$ six samples of each concentration were estimated in each assay, the solutions being distributed on the plates in a latin square design. After three hours, when the solutions had been absorbed $\overrightarrow{\vec{\omega}}$ into the agar, the plates were inverted and $\stackrel{\circ}{\circ}$ incubated at $37^{\circ} \mathrm{C}$ for 24 hours and then the $\stackrel{\circ}{=}$ zones of digestion were measured in two directions at right angles. After averaging the zones produced by each different solution and sub- $\dot{\omega}$ tracting the cup diameter, the average zone $\stackrel{\vec{A}}{A}$ sizes produced in the presence of the drug were ㅇ compared with those produced by pepsin alone. $\rightarrow$ Graphs were plotted of inhibition of peptic $\frac{D}{2}$ activity by the drugs at each concentration of pepsin.

\section{Materials Used}

HAEMOGLOBIN

Bovine, enzyme substrate powder, Piece Chemical Company, Illinois.

\section{PEPSIN}

Hog stomach $3 \times$ crystallized from diluted alcohol, Mann Research Laboratories, New York.

\section{CARBENOXOLONE}

The carbenoxolone used was prepared in the May \& Baker Research Laboratories by $\mathrm{Dr}$. M. P. L. Caton by the reaction of glycyrrhetinic $\mathcal{O}^{\circ}$ acid with succinic anhydride in boiling pyridine. The product was crystallized from aqueous 0 methanol and had $\mathrm{mp} 317-320^{\circ} \mathrm{C}$ (decomp.). $\omega$ (Finney and Tarnoky (1960) give $\mathrm{mp} 315-7^{\circ} \mathrm{C}$.) (Found: C, 71.6; H, 8.8. Calc. for $\mathrm{C}_{36} \mathrm{H}_{50} \mathrm{O}_{7}: \mathrm{C}$,

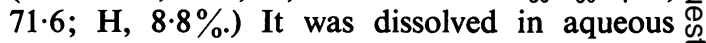
sodium bicarbonate and the $p \mathrm{H}$ was adjusted to $?$ $7 \cdot 0-8 \cdot 0$. One batch of material was used for the acute and in-vitro experiments whilst a second $\vec{\Phi}$ batch of carbenoxolone was employed in the $\frac{?}{\mathbb{D}}$ chronic experiment. The glycyrrhetinic acid used $\cong$ was obtained from Fluka A.G. (Switzerland). This did not dissolve completely in bicarbonate 8 and was administered as a suspension in bi-을 carbonate, again adjusted to $p \mathbf{H} 7 \cdot 0-8 \cdot 0$. Suspensions of Roter (F.A.I.R.) and Ebimar (Evans $\rightleftharpoons$ Medical) were prepared as described in method 3.

Spironolactone, administered in chronic experiments, was obtained from Aldactone A 
tablets crushed and dissolved in carbenoxolone solution.

\section{Results}

EFFECT ON PEPTIC ACTIVITY AND GASTRIC ACID CONCENTRATION OF PYLORUS-

LIGATED RATS

After pretreatment with carbenoxolone (12.5 to $200 \mathrm{mg} / \mathrm{kg}$ orally), no changes were seen in the volume of gastric juice or in $\mathrm{K}^{+}$concentration (Table Ic). However, a dose-dependent inhibition of peptic activity was observed (Fig. 1 and Table Ia). In comparison with the control rats, doses of carbenoxolone above $12.5 \mathrm{mg} / \mathrm{kg}$ orally produced increasing degrees of inhibition, culminating in a complete loss of peptic activity after $200 \mathrm{mg} / \mathrm{kg}$ had been given orally. There was also a reduction in total acid with all doses of carbenoxolone (Fig. 1 and Table Ib), but this effect was less marked than peptic inhibition. Glycyrrhetinic acid was less effective than carbenoxolone in

\begin{tabular}{|c|c|c|c|c|c|c|c|c|c|}
\hline \multirow[t]{2}{*}{ Compound } & \multirow{2}{*}{$\begin{array}{l}\text { Oral } \\
\text { Dose } \\
(m g / k g)\end{array}$} & \multicolumn{2}{|l|}{ Treated } & \multicolumn{2}{|l|}{ Control } & \multirow[t]{2}{*}{$D$} & \multirow[t]{2}{*}{$t$} & \multirow[t]{2}{*}{$\boldsymbol{P}$} & \multirow{2}{*}{$\begin{array}{l}\text { Percentage } \\
\text { Inhibition }\end{array}$} \\
\hline & & $\begin{array}{l}\text { Mean Pepsin } \\
\text { Concentration } \\
\left(\mu g / m l \times 10^{2}\right)\end{array}$ & $S E$ & $\begin{array}{l}\text { Mean Pepsin } \\
\text { Concentration } \\
\left(\mu \mathrm{g} / \mathrm{ml} \times 10^{2}\right)\end{array}$ & $S E$ & & & & \\
\hline \multirow[t]{2}{*}{$\begin{array}{l}\text { Carbenoxolone } \\
\text { sodium }\end{array}$} & $\begin{array}{r}200 \\
100 \\
50\end{array}$ & $\begin{array}{cc}0.5 & (6) \\
12.83 & (6) \\
21.83 & (6)\end{array}$ & $\begin{array}{l} \pm c \cdot 34 \\
\pm 3 \cdot 51 \\
\pm 2 \cdot 55\end{array}$ & $\begin{array}{ll}45 & (5) \\
52 \cdot 5 & (6) \\
47 \cdot 75 & (4)\end{array}$ & $\begin{array}{l} \pm 3 \cdot 36 \\
\pm 1 \cdot 43 \\
\pm 5 \cdot 19\end{array}$ & $\begin{array}{l}5 \cdot 05 \\
6 \cdot 56 \\
8 \cdot 04\end{array}$ & $\begin{array}{r}14 \cdot 72 \\
10 \cdot 48 \\
5 \cdot 00\end{array}$ & $\begin{array}{l}<0.0005 \\
<0.0005 \\
<0.0025 \\
>0.0005\end{array}$ & $\begin{array}{l}99 \cdot 0 \\
75 \cdot 6 \\
54 \cdot 3\end{array}$ \\
\hline & $\begin{array}{l}25 \\
12 \cdot 5\end{array}$ & $\begin{array}{ll}23 \cdot 3 & (9) \\
33 \cdot 16 & (6)\end{array}$ & $\begin{array}{l} \pm 2 \cdot 53 \\
\pm 3.02\end{array}$ & $\begin{array}{ll}39 \cdot 43 & (7) \\
35 \cdot 50 & (4)\end{array}$ & $\begin{array}{l} \pm 0.95 \\
\pm 5.58\end{array}$ & $\begin{array}{l}5 \cdot 97 \\
8 \cdot 98\end{array}$ & $\begin{array}{l}5 \cdot 35 \\
0 \cdot 40\end{array}$ & $\begin{array}{l}<0.0005 \\
<0.35 \\
>0.30\end{array}$ & $\begin{array}{r}40.9 \\
6.6\end{array}$ \\
\hline $\begin{array}{l}\text { Glycyrrhetinic } \\
\text { acid }\end{array}$ & $\begin{array}{r}200 \\
100 \\
50\end{array}$ & $\begin{array}{ll}19 \cdot 8 & (8) \\
27 \cdot 3 & (10) \\
44 \cdot 17 & (6)\end{array}$ & $\begin{array}{l} \pm 3 \cdot 29 \\
\pm 2 \cdot 52 \\
\pm 1 \cdot 94\end{array}$ & $\begin{array}{ll}42 \cdot 7 & (10) \\
46 \cdot 19 & (7) \\
41 \cdot 83 & (6)\end{array}$ & $\begin{array}{l} \pm 6.83 \\
\pm 3.90 \\
\pm 4.04\end{array}$ & $\begin{array}{l}8 \cdot 02 \\
8 \cdot 98 \\
7 \cdot 23\end{array}$ & $\begin{array}{l}6 \cdot 0 C \\
4.47 \\
0.56\end{array}$ & $\begin{array}{l}<0.0005 \\
<0.0005 \\
<0.030 \\
>0.25\end{array}$ & $\begin{array}{r}53 \cdot 5 \\
41 \cdot 0 \\
-5 \cdot 6\end{array}$ \\
\hline
\end{tabular}

Table Ia Effect of carbenoxolone sodium and glycyrrhetinic acid on peptic activity of gastric juice obtained from anaesthetized pylorus-ligated rats ${ }^{1}$

${ }^{1}$ Figures refer to the mean pepsin concentration in gastric juice obtained from rat stomach removed four hours after the drug was administered and pyloric ligation. Figures in brackets refer to the number of experiments.

\begin{tabular}{|c|c|c|c|c|c|c|c|}
\hline \multirow[t]{3}{*}{ Compound } & \multirow{3}{*}{$\begin{array}{l}\text { Oral } \\
\text { Dose } \\
(m g / k g)\end{array}$} & \multicolumn{6}{|c|}{ Mean Total $\mathrm{H}^{+}$Concentration } \\
\hline & & \multicolumn{2}{|l|}{ Experimental } & \multicolumn{2}{|l|}{ Control } & \multirow[t]{2}{*}{$\boldsymbol{P}$} & \multirow{2}{*}{$\begin{array}{l}\text { Percentage } \\
\text { Change in } \\
\text { Experimentals } \\
\text { cf Controls }\end{array}$} \\
\hline & & $\begin{array}{l}\text { Value } \\
(m-e q u i v / 1 \times 10)\end{array}$ & $S E$ & $\begin{array}{l}\text { Value } \\
(m-\text { Equiv/ } 1 \times 10)\end{array}$ & $S E$ & & \\
\hline Carbenoxolone & $\begin{array}{c}200 \\
100 \\
50 \\
25 \\
12 \cdot 5\end{array}$ & $\begin{array}{l}9 \cdot 41 \\
5 \cdot 88 \\
6 \cdot 49 \\
9 \cdot 88 \\
6 \cdot 48\end{array}$ & $\begin{array}{l} \pm 1.32 \\
\pm 2.06 \\
\pm 0.90 \\
\pm 0.16 \\
\pm 0.87\end{array}$ & $\begin{array}{r}13 \cdot 44 \\
11 \cdot 89 \\
9 \cdot 13 \\
12 \cdot 87 \\
7 \cdot 91\end{array}$ & $\begin{array}{l} \pm 0.48 \\
\pm 0.52 \\
\pm 0.45 \\
\pm 0.27 \\
\pm 0.06\end{array}$ & $\begin{array}{l}0.0125-0.01 \\
0.025-0.0125 \\
0.025-0.0125 \\
<0.0005 \\
0.025-0.0125\end{array}$ & $\begin{array}{l}-29 \cdot 7 \\
-47 \cdot 5 \\
-28 \cdot 9 \\
-23 \cdot 3 \\
-17 \cdot 9\end{array}$ \\
\hline Glycyrrhetinic acid & $\begin{array}{r}200 \\
100 \\
50\end{array}$ & $\begin{array}{r}6 \cdot 75 \\
10 \cdot 77 \\
8 \cdot 84\end{array}$ & $\begin{array}{l} \pm 0.37 \\
\pm 0.53 \\
\pm 0.41\end{array}$ & $\begin{array}{r}6 \cdot 25 \\
10 \cdot 74 \\
7 \cdot 15\end{array}$ & $\begin{array}{l} \pm 0.13 \\
\pm 0.54 \\
\pm 0.44\end{array}$ & $\begin{array}{l}0.1-0.05 \\
0.45-0.4 \\
0.05-0.025\end{array}$ & $\begin{array}{r}+8.0 \\
+2.8 \\
+23.3\end{array}$ \\
\hline
\end{tabular}

Table Ib Total $\mathrm{H}^{+}$Concentration in gastric juice obtained by four-hour pyloric ligation in anaesthetized rats determined by titration against $\frac{N}{100} \mathrm{NaOH}$

\begin{tabular}{|c|c|c|c|c|c|}
\hline \multirow[t]{2}{*}{ Compound } & \multirow{2}{*}{$\begin{array}{l}\text { Oral } \\
\text { Dose } \\
\text { ( } m g / k g)\end{array}$} & \multicolumn{2}{|c|}{$\begin{array}{l}\text { Mean Volume Juice } \\
\text { Secreted }(m l)\end{array}$} & \multicolumn{2}{|c|}{$\begin{array}{l}\text { Mean } K^{+} \text {Concentration } \\
(p p m \times 10)\end{array}$} \\
\hline & & Experimental & Control & Experimental & Control \\
\hline Carbenoxolone & $\begin{array}{l}200 \\
100 \\
50 \\
25 \\
12.5\end{array}$ & $\begin{array}{l}3 \cdot 70 \\
3 \cdot 73 \\
3 \cdot 37 \\
4 \cdot 92 \\
2 \cdot 50\end{array}$ & $\begin{array}{l}4.20 \\
2.83 \\
4.71 \\
4.98 \\
1.86\end{array}$ & $\begin{array}{l}24 \cdot 33 \\
26 \cdot 57 \\
28 \cdot 90 \\
27 \cdot 10 \\
34 \cdot 88\end{array}$ & $\begin{array}{l}29 \cdot 04 \\
35 \cdot 84 \\
27 \cdot 25 \\
28 \cdot 50 \\
32 \cdot 80\end{array}$ \\
\hline $\begin{array}{l}\text { Glycyrrhetinic } \\
\text { acid }\end{array}$ & $\begin{array}{r}200 \\
100 \\
50\end{array}$ & $\begin{array}{l}4.63 \\
4.66 \\
3.98\end{array}$ & $\begin{array}{l}3.32 \\
3.77 \\
3.75\end{array}$ & $\begin{array}{c}21 \cdot 74 \\
23 \cdot 44 \\
19 \cdot 88\end{array}$ & $\begin{array}{l}26.93 \\
26.09 \\
19 \cdot 23\end{array}$ \\
\hline
\end{tabular}

Table Ic Effect of carbenoxolone and glycyrrhetinic acid on volume of gastric juice and $K^{+}$concentration in anaesthetized pylorus-ligatedrats reducing peptic activity and had no effect on total acid. No experiments were carried out with degraded carrageenan or with Roter in this test.

After chronic dosing the peptic activity of all three groups of rats was lower than that seen in acute experiments. After 17 days' pretreatment both treated groups had less peptic activity than the controls but this trend was not significant when tested with Student's t test. After 23 days' pretreatment the combination of carbenoxolone and spironolactone caused a significant suppression of peptic activity compared with that in the controls but the carbenoxolone-treated animals gave a slightly higher value than the 


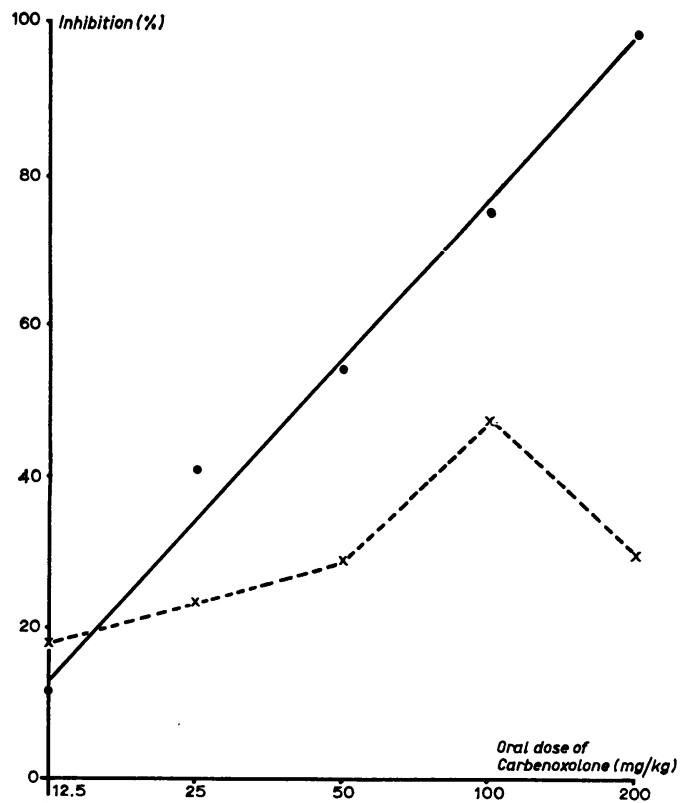

Fig. 1 Effect of carbenoxolone sodium on peptic activity and total acid concentration of the rat gastric secretion

Mean values of peptic activity and of total acid concentration of gastric juice obtained from groups of six to 10 anaesthetized rats after four hours' pyloric ligation and pretreated with carbenoxolone sodium compared to the mean values of control groups of rats.

The results are expressed as the percentage reduction from the mean control value.

\section{Peptic activity}

$\ldots+\ldots \ldots$ - $-\ldots$ Total acid concentrution controls. There were no trends in the results for the volume of juice secreted, total acidity, or $\mathrm{K}^{+}$concentration. These results are summarized in Table II. No consistent or significant differences were found in the average food and water intake per $100 \mathrm{~g}$ body weight per day or in the rate of increase of body weight.

\section{ANTIPEPTIC ACTIVITY IN VITRO}

\section{Haemoglobin digestion}

Both carbenoxolone and Roter reduced peptic activity in vitro, the former being some 10 times more active than Roter when the latter's activity was expressed as bismuth subnitrate (Table III). In this test Ebimar did not give reproducible results when amounts of carrageenan up to $18 \mathrm{mg}$ were used. Glycyrrhetinic acid was not evaluated in this test.

\begin{tabular}{lcl}
\hline Compound & Dose $(\mu \mathrm{g})$ & $\begin{array}{l}\text { Percentage } \\
\text { Inhibition }\end{array}$ \\
\hline At $\mathrm{p} H$ 2.0 & & \\
Carbenoxolone & 250 & $54 \cdot 7$ \\
& 125 & $62 \cdot 8$ \\
& $62 \cdot 5$ & $51 \cdot 2$ \\
Roter & $31 \cdot 25$ & $33 \cdot 7$ \\
& 1,000 & $43 \cdot 0$ \\
& 750 & $50 \cdot 2$ \\
At pH 3.6 & 500 & $16 \cdot 7$ \\
Carbenoxolone & & \\
& 2,500 & $96 \cdot 3$ \\
& 1,250 & $75 \cdot 2$ \\
& 625 & $24 \cdot 3$ \\
& $312 \cdot 5$ & $5 \cdot 9$ \\
\hline
\end{tabular}

Table III Antipeptic activity in vitro as measured in the haemoglobin pepsin assay

\begin{tabular}{|c|c|c|c|c|c|c|c|c|c|}
\hline $\begin{array}{l}\text { Duration } \\
\text { of } \\
\text { Treatment } \\
\text { (days) }\end{array}$ & Treatment & $\begin{array}{l}\text { Mean } \\
\text { Volume } \\
\text { Juice } \\
\text { Secreted } \\
(m l)\end{array}$ & $\begin{array}{l}\text { Mean Pepsin } \\
\text { Concentration } \\
\left(\mu g / m l \times 10^{2}\right)\end{array}$ & $\pm S E$ & $P^{2}$ & $\begin{array}{l}\text { Mean Total } \mathrm{H}^{+} \\
\text {Concentration } \\
(m-\text { equiv } / 1 \times 10)\end{array}$ & $\pm S E$ & $P^{2}$ & $\begin{array}{l}\text { Mean } \mathrm{K}^{+} \\
\text {Concentration } \\
(p p m \times 10)\end{array}$ \\
\hline \multirow[t]{2}{*}{17} & $\begin{array}{l}\text { Control } \\
\text { Carbenoxolone } \\
\text { sodium }\end{array}$ & $\begin{array}{l}4 \cdot 25 \\
3 \cdot 89\end{array}$ & $\begin{array}{l}21 \cdot 5 \\
18 \cdot 0\end{array}$ & $\begin{array}{l}1 \cdot 5 C \\
1 \cdot 46\end{array}$ & \multirow{2}{*}{$\begin{array}{l}<0.10 \\
>0.05 \\
<0.025 \\
>0.0125\end{array}$} & $\begin{array}{l}13 \cdot 5 \\
13.8\end{array}$ & $\begin{array}{l}1 \cdot 08 \\
2 \cdot 18\end{array}$ & \multirow{2}{*}{$\begin{array}{l}<0.4875 \\
>0.475 \\
<0.05 \\
>0.025\end{array}$} & $\begin{array}{l}26 \cdot 0 \\
26 \cdot 7\end{array}$ \\
\hline & $\begin{array}{l}\text { Carbenoxolone } \\
\text { sodium } \\
\text { + spironolactone }\end{array}$ & $3 \cdot 51$ & $16 \cdot 3$ & $1 \cdot 38$ & & $11 \cdot 1$ & $8 \cdot 71$ & & $38 \cdot 0$ \\
\hline \multirow[t]{2}{*}{23} & $\begin{array}{l}\text { Control } \\
\text { Carbenoxolone } \\
\text { sodium }\end{array}$ & $\begin{array}{l}2.91 \\
3.04\end{array}$ & $\begin{array}{l}21 \cdot 9 \\
24 \cdot 8\end{array}$ & $\begin{array}{l}1 \cdot 82 \\
3 \cdot 25\end{array}$ & \multirow{2}{*}{$\begin{array}{l}<0.25 \\
>0.20 \\
<0.005 \\
>0.0025\end{array}$} & $\begin{array}{l}9 \cdot 1 \\
9 \cdot 8\end{array}$ & $\begin{array}{l}12 \cdot 6 \\
1 \cdot 25\end{array}$ & \multirow{2}{*}{$\begin{array}{l}<0.4995 \\
>0.4975 \\
<0.0005\end{array}$} & $\begin{array}{l}31 \cdot 8 \\
35 \cdot 8\end{array}$ \\
\hline & $\begin{array}{l}\text { Carbenoxolone } \\
\text { sodium } \\
\pm \text { spironolactone }\end{array}$ & $2 \cdot 43$ & $17 \cdot 4$ & 3.65 & & 9.9 & 0.06 & & 33.8 \\
\hline
\end{tabular}

Table II Effect of chronic administration of carbenoxolone sodium (10 mg/kg p.o.) with or without spironolactone $(2.5 \mathrm{mg} / \mathrm{kg}$ p.o.) on parameters of gastric secretion obtained from anaesthetized four-hour pylorusligated rats ${ }^{1}$

${ }^{1}$ Figures refer to mean values determined in gastric juice obtained from the rat stomach removed four hours after the final administration of the drug and pyloric ligation.

As compared with control group of animals in the same column and experiment. 


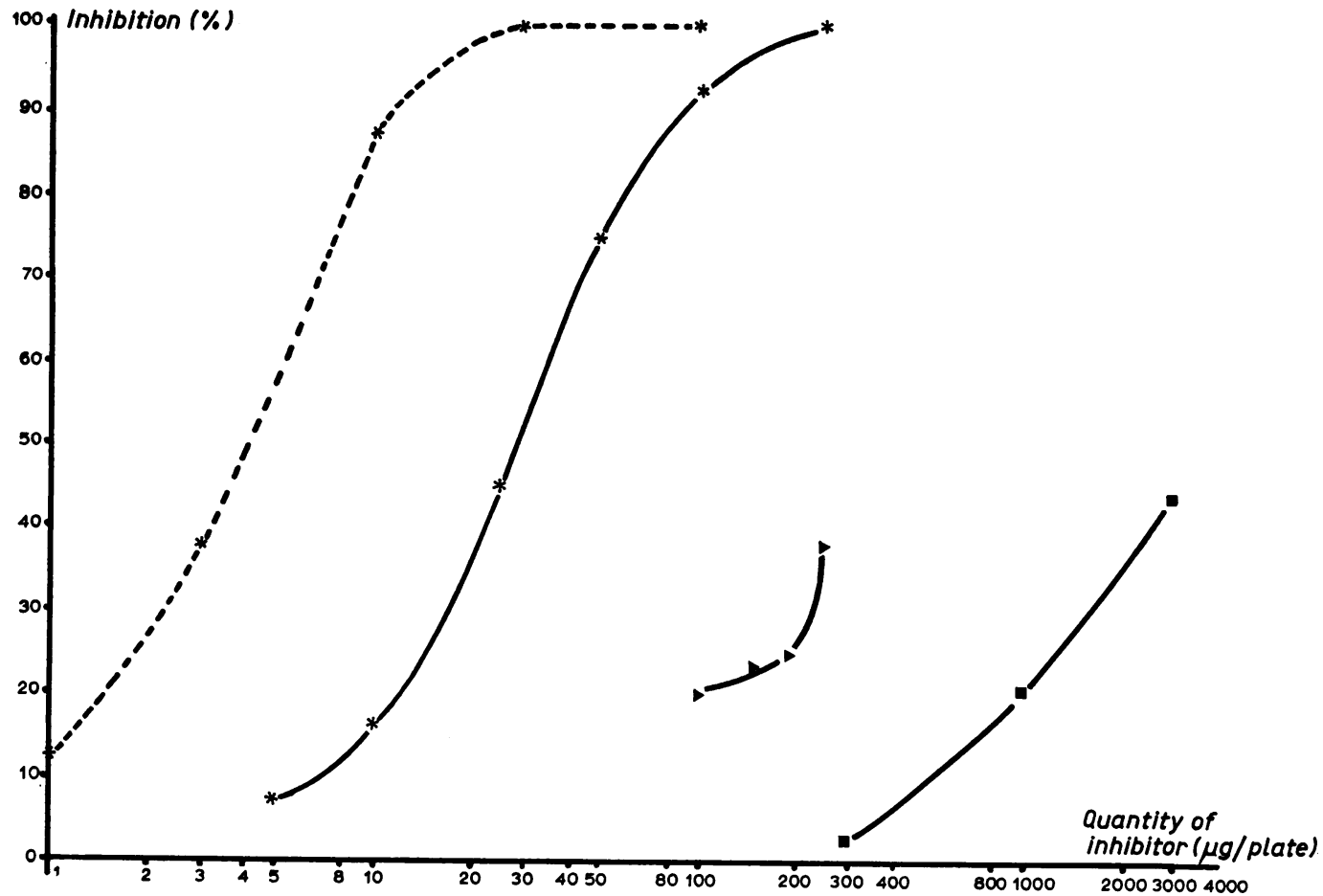

Fig. 2 Effect of carbenoxolone sodium, degraded carrageenan, and Roter on peptic activity in vitro as assessed by the pepsin plate technique.

_ $\ldots$ - $\ldots$ _ $* \ldots$ - Carbenoxolone against

$1 \mu g$ pepsin

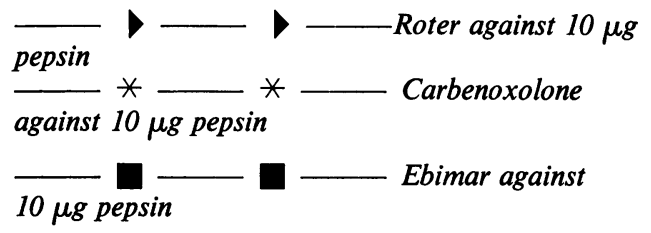

Each point represents the percentage reduction of the mean zone diameter produced by peptic digestion for 24 hours at $37^{\circ} \mathrm{C}$ when the inhibitor was present.

\section{Pepsin plates}

In the pepsin plate experiments, dose-dependent inhibition of peptic digestion similar to that seen in pylorus-ligated rats was observed with carbenoxolone, complete inhibition of $10 \mu \mathrm{g}$ pepsin being achieved with $250 \mu \mathrm{g}$ carbenoxolone (Figure 2). The percentage of peptic inhibitioncarbenoxolone concentration curve obtained with $1 \mu \mathrm{g}$ pepsin was parallel to that obtained using $10 \mu \mathrm{g}$ pepsin. Some eight to 10 times more carbenoxolone was required to produce inhibition of $10 \mu \mathrm{g}$ of pepsin compared with $1 \mu \mathrm{g}$ of peptic.

Both Roter and Ebimar produced inhibition in this experiment, but the concentration of the material required showed that both were considerably less active than carbenoxolone (Figure 2).

\section{Discussion}

The results reported here show a hitherto unpublished action of carbenoxolone, namely, its ability to inhibit pepsin both in vivo and in vitro. Carbenoxolone, which is the hemisuccinate of glycyrrhetinic acid, was more potent than glycyrrhetinic acid itself in inhibiting peptic activity and was also more active than both degraded carrageenan and Roter. Of those drugs currently used in the treatment of peptic ulcers, carbenoxolone represents the most potent inhibitor of pepsin.

Hausmann and Tárnoky (1966, and personal communication) were not able to see any significant trends in the gastric juice analyses which they carried out on 15 patients treated with 
carbenoxolone. However, these patients were suffering from a large variety of gastrointestinal disorders. In a single gastric ulcer patient treated with carbenoxolone for 20 days, as opposed to the 14-day treatment other patients received, they did show a reduction in both one hour basal gastric secretion volume and basal acid output. Bank et al (1967) observed a 34\% reduction in the maximal acid output (MAO) on the augmented histamine test after two weeks' treatment with carbenoxolone (100 mg, tds) as compared with a $4 \%$ reduction in placebo-treated patients. However, after four weeks' treatment only a $24 \%$ reduction was seen in carbenoxolone-treated patients as opposed to a $13 \%$ reduction in placebo-treated patients. Apart from this, no authors seem to have considered effects on gastric secretion parameters, other than mucin secretion, when speculating on the mode of action of this drug.

Since the doses of carbenoxolone used clinically (a maximum of $100 \mathrm{mg}$ orally tds, ie, $4.5 \mathrm{mg} / \mathrm{kg}$ ) are considerably lower than those used in the present experiments, it might well be argued that the effects described here are irrelevant. However, comparative pharmacology is not sufficiently advanced to allow dogmatic prediction of results in one species purely on results from another species. Furthermore, we do not know what degree of inhibition of peptic activity is required for a beneficial effect to become apparent on peptic ulcer healing in man. The fact that carbenoxolone in these experiments is more effective than glycyrrhetinic acid, both in inhibiting pepsin and reducing total acid output, suggests that the effects observed with carbenoxolone may be relevant and that carbenoxolone might be expected to be more effective than glycyrrhetinic acid in the treatment of human gastric ulcers.

In the chronic experiment reported here carbenoxolone-treated animals did not show mineralocorticoid side effects despite the fact that the dose given was twice the maximal clinically used dose. It can, therefore, be argued that a larger dose and/or more prolonged administration should have been used. The effect of chronic carbenoxolone administration in the experimental situation must, therefore, still remain in doubt.

Peptic activity was reduced by carbenoxolone in vitro. Since pepsin is an albumin, the results of Whitehouse et al (1967), showing that carbenoxolone and glycyrrhetinic acid bind to bovine plasma albumin, support the idea that pepsin could be inactivated by a similar binding mechanism. They found that carbenoxolone bound more readily to bovine plasma albumin than did glycyrrhetinic acid. The effect they reported, however, was small. It is interesting that they found $o-[3-0(\beta$-carboxypropionyl)-18- $\beta$-glycyrrhetamido]benzoic acid was slightly more effective than carbenoxolone in its ability to bind with bovine plasma albumin. If protein- binding capacity is indeed the mechanism by which carbenoxolone inhibits pepsin, one might have expected that this compound would be more effective than carbenoxolone. The differences reported by Whitehouse et al, however, are small and might not be significant in an experiment in vivo.

In these experiments carbenoxolone was a far more potent antipeptic agent than 'Roterized' bismuth (Bateson, 1958; Matts, 1965) or the Ebimar carrageenan substance. The failure to show peptic inhibition with carrageenan may be explained by the hypothesis that carrageenan acts by forming a substrate-inhibitor complex (Anderson and Baillie, 1967.) In the haemoglobin pepsin assay and, to a lesser extent, in the pepsin plate, excess substrate is present. This fact seems relevant when attempting an explanation as to why this compound had only a limited use clinically since stomach contents also contain an excess of substrate whenever food is present.

The mineralocorticoid activity of carbenoxolone has proved to limit the amounts of this drug that can be used clinically, and the limitation of dosage may well explain the variability in results of clinical trials. Doll, Langman, and Shawdon (1968) have shown that the administration of spironolactone in conjunction with carbenoxolone antagonizes both the beneficial effect on peptic ulceration as well as the effects on water retention. These results strengthened the hypothesis that the mineralocorticoid effects of carbenoxolone were essential for activity. Whilst there are some structural similarities between carbenoxolone and spironolactone it is difficult to understand how spironolactone could interfere with the mode of action of carbenoxolone if the latter is acting purely as a pepsin antagonist. To what extent the peptic inhibition contributes to the beneficial clinical results is unknown, but a more potent compound with this action and no mineralocorticoid activity could help to answer this question.

The activity of carbenoxolone in experimental ulceration has been studied in these laboratories using a variety of ulcer models. No significant and consistent effect of carbenoxolone on ulcer formation was found in any of these experimental situations (Ash and Edwards, personal communication). Whilst Dean (1968) did report some protection of Wistar rats against the ulcerogenic effects of the histamine liberator $48 / 80$ by pretreatment with $10 \mathrm{mg} / \mathrm{kg} / \mathrm{day}$ orally for two weeks, the protective effect he noted was small.

Khan and Sullivan (1968) were, however, able to show that carbenoxolone in an oral dose of $25 \mathrm{mg} / \mathrm{kg} /$ day increased the rate of healing of rat gastric ulcers produced by electrocautery. Many workers feel that such studies of ulcer healing are of more value than studies of ulcer prophylaxis.

Whilst mucin stimulation has in the past been 
considered as a possible mode of action of carbenoxolone the results in this paper suggest that peptic inhibition could also be considered. If these are the prinicipal ways by which carbenoxolone helps to increase the rate of healing of gastric ulcers, one begins to understand why it is of value in treating gastric ulcers but of less value in duodenal ulcers. As gastric ulcers coexist with gastric hyposecretion, a given amount of peptic inhibition would be more significant than in duodenal ulcers where the levels of gastric secretion and peptic activity are much higher. Whilst presentation of the drug in capsules which burst in the pylorus could increase its activity in duodenal ulcers, one can speculate that a more potent pepsin antagonist would be far more effective. The recent clinical trial of Duogastrone capsules by Montgomery, Lawrence, Manton, Mendl, and Rowe (1968) would seem to suggest that carbenoxolone preparations are of less value in duodenal ulcer cases.

Molecular models show very clearly that all the functional groups lie along one side of the molecule and it might be suspected that only these groups would be involved in protein binding. The steroid-like backbone of the molecule probably only plays a non-specific role in peptic inhibition as a hydrophobic group. Schlamowitz, Shaw, and Jackson (1968) have shown, using a synthetic dipeptide substrate, that hydrophobicity greatly influences the binding energy of pepsin inhibitors.

If mineralocorticoid and peptic inhibitory effects can be dissociated then it should be possible to design compounds without the limitations of carbenoxolone.

The author wishes to thank Dr M. P. L. Caton for the preparation of carbenoxolone; Miss J. Mardell and her staff for the preparation of pepsin plates; and Miss S. Casey and Mr A. Jacobs for technical assistance.

References

Aitken, M. A., Spray, G. H., and Walters, G. (1954). Gastric pepsin and the excretion of uropepsinogen in anaemia. Clin. Sci., 13, 119-126.

Anderson, W. (1961a). The antipeptic activity of sulphated polysaccharides. J. Pharm. Pharmacol., 13, 139-147.

Anderson, W. (1961b). The effect of a sulphated polysaccharide upon the diffusion of pepsin through mucin. J. Pharm. Pharmacol., 13, 122-125T.

Anderson, W., and Baillie, A. J. (1967). Carrageenans and the proteolytic activity of human gastric secretion. J. Pharm. Pharmacol., 19, 720-728.

Anderson, W., and Harthill, J. E. (1967). Degraded and undegraded carrageenans and antipeptic activity. J. Pharm. Pharmacol., 19, 460-467.

Anson, M. L. (1938). Estimation of pepsin, trypsin, papain, and cathepsin with haemoglobin. J. Gen. Physiol., 22, 79-89.

Bank, S., Marks, I. N., Palmer, P. E. S., Groll, A., and Van Eldik, E. (1967). A trial of carbenoxolone sodium in the treatment of gastric ulceration. S. Afr. med. J., 41, 297 . 300.
Bateson, P. R. (1958). A comparative in vitro evaluation of a new bismuth salt, bismuth aluminate. J. Pharm. Pharmacol., 10, 123-131.

Carter, D. V., and Sykes, G. (1961). The assay of enzyme activity by the plate-diffusion technique. J. Pharm. Pharmacol., 13, 195-199T.

Dean, A. C. B. (1968). Protective cffect of carbenoxolene in druginduced lesions of the stomach. In A Sympasium on Carbenoxolone Sodium, edited by J. M. Robson and F. M. Sullivan, pp. 33-39. Butterworths, London.

Doll, R., Hill, I. D., Hutton, C., and Underwood, D. J., II (1962). Clinical trial of a triterpenoid liquorice compound in gastric and duodenal ulcer. Lancet, 2, 793-796.

Doll, R., Hill, I. D., and Hutton, C. F. (1965). Treatment of gastric ulcer with carbenoxolone sodium and oestrogens. Gut, 6, 19-24.

Doll, R., Langman, M. J. S., and Shawdon, H. H. (1968). Treatment of gastric ulcer with carbenoxolone: antagonistic effect of spironolactone. Gut, 9, 42-45.

Finney, R. S. H., and Somers, G. F. (1958). The anti-inflammatory activity of glycyrrhetinic acid and derivatives. J. Pharm. Pharmacol., 10, 613-620.

Finney, R. S. H., and Tárnoky, A. L. (1960). The pharmacological properties of glycyrrhetinic acid hydrogen succinate (disodium salt). J. Pharm. Pharmacol., 12, 49-58.

Fletcher, M. J., MacKay, N., and Forbes, C. D. (1967). Assessment of possible glucocorticoid activity of carbenoxolone sodium. Brit. med.J., 1, 412-413.

Hausmann, W., and Tárnoky, A. L. (1966). Biochemical effects of short-term treatment with carbenoxolone disodium. Brit.J. Pharmacol., 26, 412-420.

Hausmann, W., and Tárnoky, A. L. (1968). Clinical biochemical effects of carbenoxolone. In A Symposium on Carbenoxolone Sodium, edited by J. M. Robson and F. M. Sullivan, pp. 159-172. Butterworths, London.

Horwich, L., and Galloway, R. (1965). Treatment of gastric ulceration with carbenoxolone sodium: clinical and radiological evaluation. Brit. med. J., 2, 1274-1277.

Hunt, T. (1965). Carbenoxolone sodium in the treatment of peptic ulcer. Med. Dig. (Lond.), 10, 222-224.

Iveson, P., Parke, D. V., and Williams, R. T. (1966). The metabolic fate of $\left({ }^{14} \mathrm{C}\right)$ carbenoxolone in the rat. Biochem. J., 100, 28P.

Khan, M. H., and Sullivan, F. M. (1968). The pharmacology of carbenoxolone. In A Symposium on Carbenoxolone Sodium, edited by J. M. Robson and F. M. Sullivan, pp. 5-14. Butterworths, London.

Levey, S., and Sheinfeld, S. (1954). The inhibition of the proteolytic action of pepsin by sulfate-containing polysaccharides. Gastroenterology, 27, 625-628.

Matts, S. G. F. (1965). Further experience with bismuth aluminate in peptic ulceration and nervous dyspepsia. Brit. J. clin. Pract., 19, 569-571.

Middleton, W. R. J., Cooke, A. R., Stephen, D., and Skyring, A. P. (1965). Biogastrone in inpatient treatment of gastric ulcer: a double-blind study. Lancet, 1, 1030-1032.

Montgomery, R. D., Lawrence, I. H., Manton, D. J., Mendl, K. and Rowe, P. (1968). A controlled trial of carbenoxolone sodium capsules in the treatment of duodenal ulcer. Gut, 9, 704-706.

Parke, D. V., Pollock, S., and Williams, R. T. (1963). The fate of tritium-labelled $\beta$-glycyrrhetic acid in the rat. J. Pharm. Pharmacol., 15, 500-506.

Schlamowitz, M., Shaw, A., and Jackson, W. T. (1968). The nature of the binding of inhibitors to pepsin and the kinetics of inhibited peptic hydrolysis of $\mathrm{N}$-acetyl-L-phenylalanylL-tyrosine. J. biol. Chem., 243, 2821-2828.

Turpie, A. G. G., and Thomson, T. J. (1965). Carbenoxolone sodium in the treatment of gastric ulcer with special reference to side-effects. Gut, 6, 591-594.

Whitehouse, M. W., Dean, P. D. G., and Halsall, T. G. (1967). Uncoupling of oxidative phosphorylation by glycyrrhetic acid, fusidic acid and some related triterpenoid acids. J. Pharm. Pharmacol., 19, 533-544. 